\title{
The Paradox of Ethiopia's Underdevelopment: Endogenous Factors in Retrospect
}

\author{
Feyera Senbeta (Ph.D.)*
}

\begin{abstract}
Ethiopia is a country of diverse historical, cultural, geographical, archeological, and ecological resources and is well known as the cradle of humanity. It is also the tenth-largest country in Africa and endowed with vast land and water resources. This country was unable to translate these potential resources into positive development outcomes. This paper examines the historical perspective of Ethiopia's underdevelopment mystery under the last three regimes (i.e., Haile Selassie (Imperial), Derg, and the Ethiopian People's Revolutionary Democratic Front $(E P R D F))$. Qualitative approaches mainly interview, discussion, document analysis, and personal experiences were employed in generating relevant data that were analyzed and presented thematically. The results show that Ethiopia ranked the least in many global human development indexes such as Human Development Index, Corruption Index, and Global Hunger Index in the last decade. The underlying historical development challenges include political instability, despotic leadership, corruption, dependence on foreign aid and assistance, controlled freedom of expression, lack of diversity within unity, and inconsistent development policies. Over the last three successive regimes, the state-society relationship has been characterized by conflict, disagreement, and supremacy of state which messed up available national development opportunities. If Ethiopia has to come out of poverty and underdevelopment, it needs to improve its political stability and governance. It must be governed by 'popularly elected' not by 'selfelected leader' and put in place a system of accountability for a better future and wellbeing of its population. Consistent and pro-poor policy, good working culture, and unity in diversity must be other areas of concern for future development.
\end{abstract}

Keywords: Corruption, Development, Diversity, Ethiopia, Policy, Unity

\section{Introduction}

Ethiopia is a country with greatly varying landscapes ranging from high and rugged mountains, flat-topped plateaus, deep gorges, and incised rivers to valleys and rolling plains. With many mountains and plateaus, and abundant water resources, it is commonly known as the "roof of Africa" (Asrat, 2016) and the "water tower of Africa" (UNEP, 2010), respectively. It also possesses diverse historical, archeological, and ecological accounts. Occupying an area of about 1.1 million square kilometers, it is the tenth-largest country in Africa. The Great Rift Valley system runs from northeast to southwest and divides the country into the northwestern and southeastern highlands. The highlands give way to extensive semi-arid lowlands to the east, south, and west. The country is also the second-most populous country in Africa, with a population of around 114.9 million in 2020 (PRB, 2020). The population is greatly diverse, hosting over 80 ethnic groups of which the majority practice some sort of belief. Ethiopia has

\footnotetext{
* Addis Ababa University, Ethiopia. Email: feyera.senbeta@aau.edu.et
} 
rich cultural and natural sites; and registered many UNESCO World Heritage Sites. The country has a long and rich history with the hominid "grandmother" of Lucy (Marcus 1994; Adejumobi, 2007; Lie \& Mesfin, 2018).

A long history of human settlement and associated anthropogenic factors has therefore influenced the biophysical environment of the country for years. For example, archaeological and pollen evidence suggest that agriculture practice has influenced the natural vegetation cover of the country since ancient (Phillipson, 1985; Eshetu \& Högberg, 2000; Darbyshire et al., 2003).

Over the last ninety years, the people of Ethiopia have experienced three different types of regimes, i.e., Imperial (1930-1974), Derg (1974-1991), and EPRDF (1991-2019). Characteristically, the three regimes followed distinct political ideology and development strategies reflective of their inherent nature. The Imperial System followed the ideology of the Emperor being "Elect of God" and events assumed to be performed by the Emperor of the Empire of Ethiopia. The socialist regime is commonly known as "Derg" formally eliminated the monarchy and embraced Marxist ideology. The EPRDF ousted the Derg and elevated itself as the democratic and promising regime of a moment (Marcus, 1994; Prunier, 2015; Poluha \& Feleke, 2016).

Despite diverse political backgrounds, Ethiopia has been an icon of poverty for years (Marcus, 1994; Adejumobi, 2007; Gill, 2010); and remains one of the least developed countries in the world (Lie \& Mesfin, 2018; UNDP, 2019). Development is progress towards achieving intricate goals such as elimination of poverty, provision of employment, reduction of inequality and the guarantee of human rights (Hicks \& Streeten, 1979; World Bank, 2016; Abuiyada, 2018); and a state of achieving better human wellbeing (Nicholas, 1989; Lawan, 2008). Until now, however, Ethiopia ranked among the least developed countries in the world (UNDP, 2018, 2019). The prevalence of subsistence farming, poverty, poor infrastructure, poor housing, low standard of living, environmental degradation, and human rights abuse are some of the indicators that justify Ethiopia's underdevelopment at the moment.

Various scholars have tried to comprehend the development trajectory of Ethiopia concerning politics (Clapham, 2015; Lie \& Mesfin, 2018), poverty (Flynn, 2005), and the nature of Ethiopia's history (Marcus, 1994). Courtesy to earlier reports, this study examines 
comprehensive issues as to what factors trapped Ethiopia's development efforts for a long period. This article tries to understand the irony of Ethiopia's (under) development from a historical perspective focusing on the imperial, Derg, and EPRDF regimes by searching answers to some basic questions that include: Why does Ethiopia remain one of the least developed countries in the world in the $21^{\text {st }}$ century? This overarching question can be further decomposed into issues of resource availability, governance and leadership, and policy imperatives. A critical search of answers to these questions could hopefully uncover what went wrong and erroneous in Ethiopia's past which will serve to seek and scrutinize the future development pathways.

\section{Conceptual Framework}

Development as a concept has been contested among scholars for a long as it has often been looked at from political or economic perspectives or both. However, economic growth was regarded as central to the development endeavors up to the 1980s (Adams, 2009). Slowly, development came to be understood as a multidimensional concept that should encompass economic, social, environmental, political, and cultural components (all of them having a direct impact on the quality of human life). Thus, there is no single model of development suitable and desirable for all countries. After World War II, for example, a range of development thinking has emerged that include modernization theory, dependency theory, human development, neoliberalism, post-development, sustainable development, and millennium development goals. The archaeology of development and changing circumstances for development has contributed to such diverse thoughts (Lewis, 1998; Rapley, 2007; Pieterse, 2010).

Experiences reveal that the concepts of development of a given country have been associated with its economic growth through higher productivity (Kuznets, 1966), political stability (Shepsle \& Bonchek, 2010), the extension of rights to all social groups, and the opportunities available to get them (Bayly, 2008) and the proper functioning of institutions and organizations (Acemoglu \& Robinson, 2012). According to Remenyi (2004), development is a process rather than an outcome that changes from one state or condition to another through a course of time within the prevailing political spheres. Often development leads to improved quality of life such as social justice, equal opportunity for all citizens, equitable distribution of income, and the democratization of the development process (Agbiboa, 2012; Pritchett et al., 2013). Thus, development symbolizes the whole range of change by which an entire social system moves 
away from a condition of life widely professed as unsatisfactory towards a situation where life is considered as better (Todaro \& Smith, 2003; Remenyi, 2004; Agbiboa, 2012). In contrast, underdevelopment is recognized in the situation when the capacity of human self-reliance and satisfaction deteriorates, mainly because the means to be responsible for one's livelihood or welfare has been lost to corruption, war, human right abuse, civil unrest, or the imposed need to escape and adopt the life of a refugee (Remenyi, 2004).

Over the years, many institutions including multilateral agencies and NGOs have tried to develop global indicators of development range from economic indicators (e.g., Gross National Income, GDP) to various kinds of poverty and social inequality, education, and health, all the way down to more subjective development indicators such as happiness. In this article, these indicators are being considered to determine the paradox of Ethiopia's underdevelopment.

\section{Research Methodology}

The study employed different methods to address the research question of why Ethiopia is still underdeveloped in the $21^{\text {st }}$ century. First, secondary sources, such as existing literature on the issues of development and underdevelopment were extensively consulted to establish solid theoretical grounds as to how this key concept was conceptualized and understood by others. Based on the selected literature, a textual analysis was carried out to shed some light on the concept of development/underdevelopment. The author's personal experiences and observation of Ethiopia's development and politics over an extended period were also used to corroborate the sources and the findings. Data were collected between September and December 2019.

Besides, an interview was conducted with graduate students (35), university professors (22), and scholars (14) involved in wide ranges of specialization. The interviewed Key Informants (KIs) and their respective discipline for each scholar are abbreviated as economist (EC), sociologist (SO), historian (HI), anthologist (AN), natural resource management (NR) expert, agriculturalist (AG), demographer (DE), ecologist (EO), forester (FO), geographer (GE), environmentalist (EN), biologists (BI), politician (PO), development (DE) expert and graduate student (GS) of development studies. These abbreviations were used throughout the manuscript to authenticate the source of information for quoted sources.

The qualitative method can provide complex textual descriptions of how people perceive and experience a given research issue. It provides information about the human side of an issue - that 
is, the often paradoxical behaviors, beliefs, opinions, emotions, and relationships of individuals presented (Creswell, 2009). According to Marshall (2003), the qualitative method of data generation is very effective in identifying intangible factors, such as social norms, socioeconomic status, ethnicity, and religion, whose role in the research issue may not be readily apparent. The interview mainly focused on the questions such as: How did each interviewee make sense of Ethiopia's development trends over the years? Why does Ethiopia remain underdeveloped in the $21^{\text {st }}$ century? Then, information was thematically analyzed and interpreted accordingly.

\section{Results and Discussion}

\section{Development Trajectory of Ethiopia}

Ethiopia has tried and experienced different development pathways such as feudal, socialist, and recently revolutionary democracy and developmental state system. However, these pathways never transformed Ethiopia into prosperity and economic development - rather the move from one system to the other led to chaos and devastation of human and economic resources (Clapham, 2015; Poluha \& Feleke, 2016; Lie \& Mesfin, 2018). In this article, the development trajectory of Ethiopia focused on the recent three successive regimes, namely Imperial, Derg, and EPRDF.

The Imperial system was based on the exploitation of the peasants who used to receive a piece of land in return for serving a lord (Cohen, 1974). The era of Imperial was a period of exploitive feudalism, built on injustice and disparity, in which the government was devoted to the glory of an emperor (Clapham, 2015). This system was recognized as pairing a bureaucratic monarchy and local noblemen, who often quarreled with each other, against a deeply oppressed peasantry who did not consider themselves citizens and who usually, spoke different languages and worshipped different deities, were subjugated and dehumanized (Cohen, 1974; Ghose, 1985; Bekele et al., 2016). This led to serious grievances and uprising which finally removed the feudal system through a revolution in 1974 and brought the Derg into power (Lorch, 1995; Mayfield, 1995; Plaut, 2012).

But the way the Derg took over the feudal system was revolutionary and many underpinning and existing economic, institutional, and human resources were destroyed by the name of lord property. According to one informant, "when the peasants finally took action, it was in the form 
of a chaotic explosion of revenge. Large estates were burned and crops uprooted (KI: PO)." Derg's regime started by executing 60 imprisoned former government officials and followed by the Red Terror in which tens and thousands of people were killed because of their political stance. Derg throughout its existence was engaged in various kinds of fighting with many resistance movements and with Somalia while trying to set itself as a socialist that was not approved even by the Soviets (Prunier, 2015). The subsequent outbreak of famine (1983/1984) in the country forced population migration and villagization policy which destabilized the policy of the regime and finally led to its removal.

The erstwhile Ethiopian People Revolutionary Democratic Front (EPRDF) which came to power by removing the Derg regime in 1991, also followed by destructive episodes like the previous government and apparent institution, natural resources, and many systems were completely dismantled by the name of Derg assets. As acknowledged by one of the informants:

The civil wars that took place at different moments had damaged the resources of the country. History proved that civil war has been an integral part of most of the kings, rulers, and ministries even as of today's Ethiopia. Civil war poses a potential danger to unrest and underdevelopment (KI: $\mathrm{HI})$.

Figure 1 below demonstrates the aftermath of the change in regimes and the social, economic, and political damages that followed. This displays the discontent and disapproval of the earlier regime by the large segments of society, and the hope of showing care of warning for a newly reigned group. This exhibits that none of those regimes were loyal and transparent to their people during their governance period. These irresponsible political transformations have led the country to chaos and destruction which contributed to the low development of the country in the last nine decades (Teferra, 1984; Mayfield, 1995; Flynn, 2005; Gill, 2010). Policy formation has been and is still a top-down approach in the history of the country. No government gave damn care to its society as to what type of development policy and strategy the country needs - instead all past governments developed policies that fit well to their political gamble. This phenomenon has been and remains part and parcel of Ethiopia's history and made governments detested of alltime by a large proportion of the citizens. Whatever development policy and strategy being formulated by the government, the people have been and are still suspicious and expect a little positive outcome. State-society relations have been characterized by contention, contradiction, 
and domination, and a struggle to limit the power and domination of the state was either missed or messed upon many occasions. The state has remained dominant and resilient, coping with the resistance mainly by military and authoritarian means (Bekele et al., 2016).

\section{Figure 1: Historical Development Trends among Different Regimes of Ethiopia}

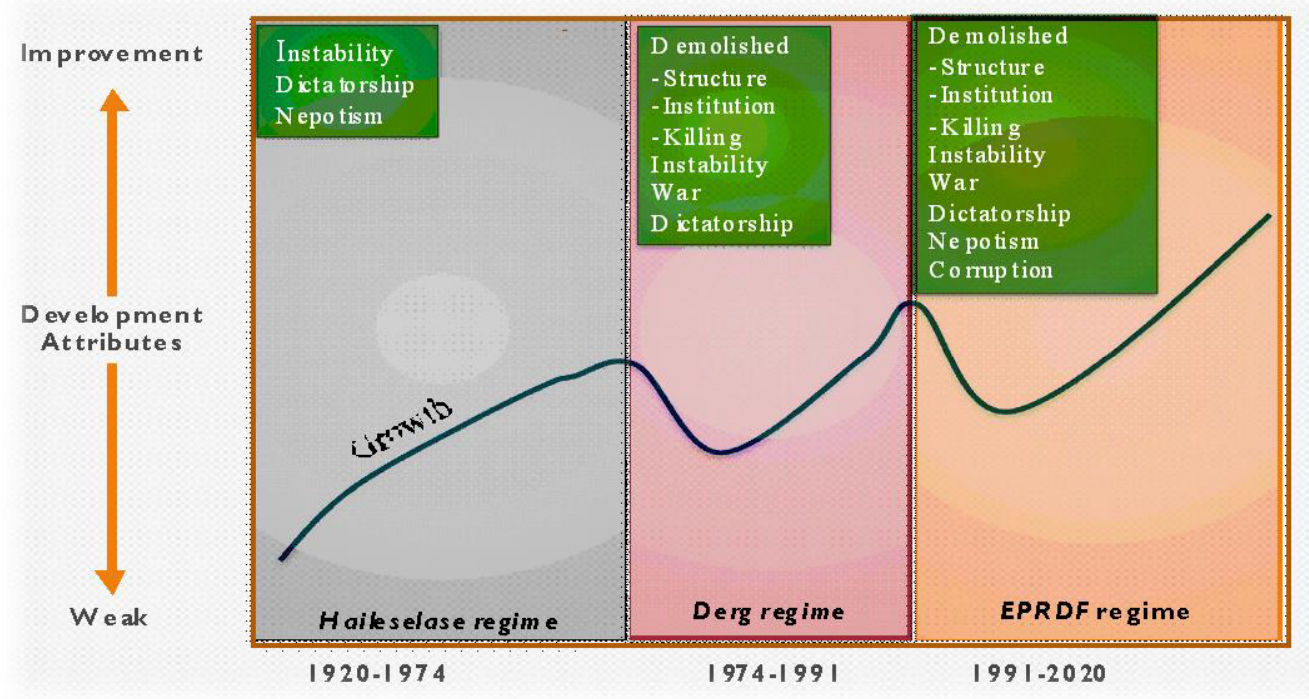

(Source: Own Development)

As time goes by, each government moves down to the politics of the blame game of the previous regime. As observed by Poluha \& Feleke (2016) that the usual narrative during the Derg period was that Ethiopia remained backward because of oppression and exploitation by the feudal system. The EPRDF period was ushered with the claim that the Derg dictatorship was, in essence, a continuation of the previous regimes and that the new order would be contributing to the welfare of the Ethiopians and rescuing them from centuries of subjugation and backwardness. Governed by the EPRDF regime for more than a quarter of a century, Ethiopia remains poor and backward by all standards (as explained in the following section). Whether the incoming regime cheerfully goes along the same pathway of blame game or not, is yet to be seen.

\section{Recent State of Human Development}

To argue rationally either in favor or against recent development trends, it is imperative to assess first the recent global human development data and compare it with that of Ethiopia. In so doing, one can realistically claim the human development trend of Ethiopia against other nations or 
regions in the world. Subsequently, the recent Ethiopia's Human Development Index, the Corruption Perceptions Index, and Global Hunger Index were comprehended as examples and compared with other countries. These are indices used globally to compare countries in terms of human, poverty, and corruption status as indicators of development. Accordingly, each index is analyzed one after the other in the following sections.

\section{Human Development Index}

The Human Development Index (HDI) measures average achievement in three basic dimensions of human development - a long and healthy life, knowledge, and a decent standard of living (UNDP, 2018). Long and healthy life is measured by life expectancy, and knowledge is measured by a combination of mean years of schooling, an average number of years of schooling, and access to learning whereas the standard of living is measured by Gross National Income (GNI) per capita (UNDP, 2019). The index counts value between 0 and 1, and an index value close to 0 and 1 shows low and high human development trends respectively. An index of less than 0.550 shows low human development while a value of 0.800 or greater shows very high human development. Index value from 0.550-0.699 shows medium human development, and 0.700-0.799 shows high human development.

In the 2018 HDI Report, Ethiopia's HDI was 0.470 and ranked 173 out of 189 countries and territories (Table 1 below). All values in 2018 and preceding years fall within the low human development group and the least as compared to different regions and global values. This confirms the low evolution of development processes in Ethiopia related to basic needs of health, education, and standard of living seen in a comparative perspective. As uttered by all informants, persistent political instability, conflicts and war, racism and nepotism, poor education, bad governance, and poor political commitment were mentioned as primary causes of low development over the years.

Table 1: Human Development Index for Ethiopia and Other Regions: 2000 and 2010-2018

\begin{tabular}{|l|l|l|l|l|l|l|l|l|l|l|l|l|l|}
\hline $\begin{array}{l}2018 \\
\text { Rank }\end{array}$ & $\begin{array}{l}\text { Categories of } \\
\text { development }\end{array}$ & Country/regions/ & 2000 & 2010 & 2011 & 2012 & 2013 & 2014 & 2015 & 2016 & 2017 & 2018 \\
\hline \multirow{2}{*}{} & & \multicolumn{7}{|c|}{ Figures of human development index } \\
\cline { 2 - 10 } & $\begin{array}{l}\text { Very High Human } \\
\text { Development }\end{array}$ & & 0.823 & 0.866 & 0.871 & 0.874 & 0.878 & 0.882 & 0.886 & 0.888 & 0.890 & 0.892 \\
\hline
\end{tabular}


PanAfrican Journal of Governance and Development, Vol. 2, No. 1, February 2021

\begin{tabular}{|c|c|c|c|c|c|c|c|c|c|c|c|c|}
\hline & $\begin{array}{l}\text { High Human } \\
\text { Development }\end{array}$ & & 0.630 & 0.706 & 0.713 & 0.720 & 0.727 & 0.733 & 0.738 & 0.743 & 0.746 & 0.750 \\
\hline & $\begin{array}{l}\text { Medium Human } \\
\text { Development }\end{array}$ & & 0.497 & 0.575 & 0.584 & 0.593 & 0.599 & 0.608 & 0.616 & 0.625 & 0.630 & 0.634 \\
\hline & $\begin{array}{l}\text { Low human } \\
\text { Development }\end{array}$ & & 0.386 & 0.473 & 0.479 & 0.484 & 0.490 & 0.496 & 0.499 & 0.501 & 0.505 & 0.507 \\
\hline $\begin{array}{l}173 \text { of } \\
188\end{array}$ & & Ethiopia & 0.283 & 0.412 & 0.423 & 0.429 & 0.439 & 0.446 & 0.453 & 0.460 & 0.467 & 0.470 \\
\hline & & $\begin{array}{l}\text { Developing } \\
\text { Countries }\end{array}$ & 0.571 & 0.642 & 0.650 & 0.657 & 0.663 & 0.669 & 0.674 & 0.680 & 0.683 & 0.686 \\
\hline & & Regions & & & & & & & & & & \\
\hline & & Arab States & 0.613 & 0.676 & 0.681 & 0.687 & 0.688 & 0.691 & 0.695 & 0.699 & 0.701 & 0.703 \\
\hline & & $\begin{array}{l}\text { East Asia and the } \\
\text { Pacific }\end{array}$ & 0.597 & 0.691 & 0.700 & 0.707 & 0.714 & 0.721 & 0.727 & 0.733 & 0.737 & 0.741 \\
\hline & & $\begin{array}{l}\text { Europe and Central } \\
\text { Asia }\end{array}$ & 0.667 & 0.735 & 0.744 & 0.750 & 0.759 & 0.766 & 0.770 & 0.772 & 0.776 & 0.779 \\
\hline & & $\begin{array}{l}\text { L. America and the } \\
\text { Caribbean }\end{array}$ & 0.687 & 0.731 & 0.737 & 0.740 & 0.748 & 0.752 & 0.754 & 0.756 & 0.758 & 0.759 \\
\hline & & South Asia & 0.505 & 0.585 & 0.593 & 0.601 & 0.607 & 0.617 & 0.624 & 0.634 & 0.639 & 0.642 \\
\hline & & Sub-Saharan Africa & 0.423 & 0.498 & 0.505 & 0.512 & 0.521 & 0.527 & 0.532 & 0.535 & 0.539 & 0.541 \\
\hline & & World & 0.641 & 0.697 & 0.703 & 0.708 & 0.713 & 0.718 & 0.722 & 0.727 & 0.729 & 0.731 \\
\hline
\end{tabular}

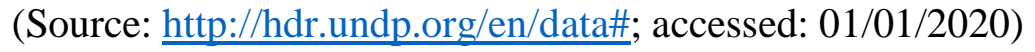

\section{Global Hunger Index (GHI)}

The Global Hunger Index (GHI) is a composite index that tries to measure and track hunger at the global, regional, and country levels by incorporating four component indicators: undernourishment, child wasting, child stunting, and child mortality (von Grebmer et al., 2019). Each indicator is given a standardized score in percentage, and scores are then aggregated to estimate the GHI score for each country. Then, the country's hunger level is evaluated on four levels: $\leq 9.9$ shows "low"; 10.0-19.9 shows "moderate"; 20.0-34.9 shows "serious"; 35.0-49.9 shows "alarming" and $\geq 50.0$ shows "extremely alarming". The 2019 GHI report ranks Ethiopia $97^{\text {th }}$ out of 117 qualifying countries with a score of 28.9 which falls within a level of hunger that is "serious". 
Feyera, S., The Paradox of Ethiopia's Underdevelopment: Endogenous Factors in Retrospect

Ethiopia has been more often involved in violent conflict and war to sustain the supremacy of leaders and their legacies (Lorch, 1995; Flynn, 2005; Gill, 2010; Plaut, 2012) which have been strong drivers of hunger and under nutrition (von Grebmer et al., 2019). Still, every year, the country is experiencing hunger that makes millions of people depend on food aid to keep them alive. Development has yet to reach the great majority of the population and much of the country's wealth - and political power - has been retained by the leaders and ruling party (Peebles, 2013).

\section{Corruption Perceptions Index (CPI)}

The Corruption Perceptions Index (CPI) is a composite index published annually by Transparency International since 1995 to measure perceptions of corruption in the public sector (Transparency International, 2020). The CPI ranks countries "on a scale from 100 (very clean) to 0 (highly corrupt)". According to the 2020 CPI report, Ethiopia is listed 96 out of 180 countries with a value of 37 (Table 2 below). Comparatively, the 2019 Ethiopian corruption scale (37) is more close to the highly corrupted countries (e.g., Sudan, Kenya) than the less corrupted countries (e.g., New Zealand, Denmark) which demonstrates the seriousness of the problem. Meager improvement has been observed over the last seven years which implies continued corruption challenges for the social, economic, and political transformation of the country. A large proportion of the study informants noted corruption to be a grave challenge that undermined development efforts in the country over the years.

Table 2: 2012-2019 Corruption Perceptions Index of Ethiopia and Some Selected Countries.

\begin{tabular}{|l|c|c|c|c|c|c|c|c|c|}
\hline \multirow{2}{*}{ Country } & \multirow{2}{*}{ Rank 2019 } & \multicolumn{6}{|c|}{ Corruption Perceptions Index Score: 2012-2019 } \\
\cline { 3 - 10 } & & $\mathbf{2 0 1 9}$ & $\mathbf{2 0 1 8}$ & $\mathbf{2 0 1 7}$ & $\mathbf{2 0 1 6}$ & $\mathbf{2 0 1 5}$ & $\mathbf{2 0 1 4}$ & $\mathbf{2 0 1 3}$ & $\mathbf{2 0 1 2}$ \\
\hline New Zealand & 1 & 87 & 87 & 89 & 90 & 91 & 91 & 91 & 90 \\
\hline Denmark & 1 & 87 & 88 & 88 & 90 & 91 & 92 & 91 & 90 \\
\hline Norway & 7 & 84 & 84 & 85 & 85 & 88 & 86 & 86 & 85 \\
\hline Botswana & 34 & 61 & 61 & 61 & 60 & 63 & 63 & 64 & 65 \\
\hline Senegal & 66 & 45 & 45 & 45 & 45 & 44 & 43 & 41 & 36 \\
\hline South Africa & 70 & 44 & 43 & 43 & 45 & 44 & 44 & 42 & 43 \\
\hline Ethiopia & 96 & 37 & 34 & 35 & 34 & 33 & 33 & 33 & 33 \\
\hline
\end{tabular}


PanAfrican Journal of Governance and Development, Vol. 2, No. 1, February 2021

\begin{tabular}{|l|c|c|c|c|c|c|c|c|c|}
\hline Zambia & 113 & 34 & 35 & 37 & 38 & 38 & 38 & 38 & 37 \\
\hline Djibouti & 126 & 30 & 31 & 31 & 30 & 34 & 34 & 36 & 36 \\
\hline Kenya & 137 & 28 & 27 & 28 & 26 & 25 & 25 & 27 & 27 \\
\hline Nigeria & 146 & 26 & 27 & 27 & 28 & 26 & 27 & 25 & 27 \\
\hline Eritrea & 160 & 23 & 24 & 20 & 18 & 18 & 18 & 20 & 25 \\
\hline Sudan & 173 & 16 & 16 & 16 & 14 & 12 & 11 & 11 & 13 \\
\hline
\end{tabular}

(Source: Transparency International, 2020)

Chronological analysis of successive Ethiopian governments also displays the presence of systematic and rampant corruption. There are many idioms that support the presence of overwhelming corruption in the society. As an example, there is a proverb stated as "Sishom yalbela sishar yiqochewal" that means, "if someone does not deprive during his/her reign, he/she will regret when he/she loses the power". Likewise, another proverb is stated as "Semay aytaresim; nigus ayikesesim" loosely translated as "as it is impossible to plough the sky, accusing the king is impossible". These and other proverbs support and define corruption as acceptable norm in the society. Ethiopia is challenged by a kind of corruption known as 'State Capture'. It is a practice in which commanding groups exert their corrupt and unfounded influence on others in order to shape the institutions and policies, laws and regulations of the state for their benefit rather than for the public service (Broadman \& Recanatini, 2001; Hassan, 2016).Transparency International's expression stands to be good evidence as to the extent to which corruption can damage the social, political, and economic development efforts of a nation:

Corruption is a major obstacle to democracy and the rule of law. It is extremely challenging to develop accountable political leadership in a corrupt climate. Economically, corruption depletes national wealth. Corrupt politicians invest scarce public resources in projects that will line their pockets rather than benefit communities and prioritize high-profile projects such as dams, power plants, pipelines, and refineries over less spectacular but more urgent infrastructure projects such as schools, hospitals, and roads. Corruption also hinders the development of fair market structures and distorts competition, which in turn deters investment (http://www.transparency.org). 
Corruption is widely regarded as one of the biggest impediments to economic growth, social development, and environmental sustainability (Smith et al., 2010; Agbiboa, 2012). In all of its form, corruption is an evil, an unethical set of activities that misplaces resources from where it is most needed to where it is easily wasted. Lack of political will and commitments are partly contributing factors to reduce the damaging effects of corruption in Ethiopia.

\section{Despotic Leaders and Their Legacies}

Regardless of their political, ideological, educational, social, and economic differences, Ethiopian leaders traded terrible leadership characters such as cruelty, brutality, intimidation, etc. (As shown in Table 3 below). According to Kets de Vries (2004), in societies where there are weak democratic traditions and institutions, political systems and/or an ineffective judiciary, and economic distress, they are usually vulnerable to tyrants; and these situations facilitate a power grab by a power-hungry despot.

For example, Haile Selassie kept Ethiopia as a land of misery where the feudal system ridiculed suppression and dehumanization and built the country around his beliefs (Lorch, 1995; Plaut, 2012). Revolts, rebellions, droughts, and famine marked Haile Selassie's reign although he proclaimed himself as a "King of Kings of Ethiopia". Protests and demonstrations against the emperor led to the overthrow and the accession of Mengistu Hailemariam to power in 1974 (Mayfield, 1995). Mengistu formally abolished the monarchy and embraced communism and shifted the geopolitical path from the West to the East (Keller 1991; Lie \& Mesfin, 2018). Instead of dialogue, Mengistu preferred warfare against Eritrean independence forces, Somalia invaders, and ethnic-based insurgencies by Tigray Liberation Front (TPLF) in the north and Oromo Liberation Front (OLF) in the south (Lie \& Mesfin, 2018). As a result, tens of thousands of people were killed, including the emperor, and many were tortured and a million peasants were relocated (Lorch, 1995; Gill, 2010; Plaut, 2012).

Following the fall of Mengistu in 1991, Meles Zenawi established a nominally multi-party system. Despite the initial promising signs, the government's human rights record was oppressive, undemocratic, brutal, and governed by a powerful party in which there was no distinction between party and state (HRW/Africa, 1997; HRW, 2010; Plaut, 2012; Peebles, 2013). Many human rights advocates report that the government has tried all its best to suppress its political opponents, and killed/imprisoned tens of thousands of people in Oromia, Somali, 
Gambella, Southern, and the other Regional States. Following the unexpected death of Meles in 2012, Hailemariam Desalegn (2012-2018) led Ethiopia for about six years and gave up his leadership in 2018. Hailemariam's headship was characterized by humanitarian, political, and security crises like his forerunners; and finally forced to give up his position. As a leader during his period, more often, he claimed to maintain and uphold the legacy of Meles.

Three years of persistent anti-government protests in Oromia, Amhara, and the Southern Regional States have eventually led to the upcoming of Abiy Ahmed's leadership. Upon assuming the position, Abiy started releasing prisoners and invited exiled movements to return home for the democratic course including armed groups. He also re-established bilateral relations with Eritrea that was frozen for two decades, and this attracted the Norwegian Nobel Committee to award Abiy the Nobel Peace Prize in October 2019. Within the country, however, adversary regional, ethnic and political factions conflict over ideology, power, and resources, has led to the killing of thousands of people and displacing more than three million people (ICG, 2020). The security forces more often engaged in intimidation, killing, and even decree unofficial State of Emergency in many parts of the country. Both local and global human rights advocates have severely criticized and expressed their concern about harassment and intimidation in the country (HRLHA, 2020; HRW, 2020; ICG, 2020). Since he crowned, his government has more often undermined the existing ethnic federalism and apprehend unitary state system often advocates the heritage of traditional monarchs on top of human right abuses. This situation has already created significant polarization among the elites/politicians in the country into the unitary $v s$. federalism pathway of state-building.

Over the past decades, the Ethiopian leaders exercised a brutal type of governance system where freedoms of speech and human rights abuses were the common denominators for all. Long years of dictatorial leadership have hardly helped Ethiopia's development. This continued underdevelopment was not because of a lack of resources, rather due to a lack of dedicated leaders who can strive to transform the country to prosperity. Each coming and going leaders turn-by-turn tried to lay down their wicked legacy while Ethiopia has been and remains the land of misery owing to famine, war, poverty, tyrant leaders, and human right abuse (Flynn, 2005; Gill, 2010; Lie \& Mesfin, 2018; Lorch, 1995; Mayfield, 1995; Plaut, 2012). On the contrary, none of them accounted for what they did to the people and the nation. 
Feyera, S., The Paradox of Ethiopia's Underdevelopment: Endogenous Factors in Retrospect

Table 3: Some Attributes of Ethiopian Leaders and Their Resemblance

\begin{tabular}{|c|c|c|c|c|c|}
\hline \multirow[b]{2}{*}{ Attributes } & \multicolumn{5}{|c|}{ Name of Ethiopian Leaders } \\
\hline & $\begin{array}{c}\text { Haile Selassie } \\
(1930-1974)\end{array}$ & $\begin{array}{c}\text { Mengistu Hailemariam } \\
\text { (1974-1991) }\end{array}$ & $\begin{array}{c}\text { Meles Zenawi } \\
(1991-2012)\end{array}$ & $\begin{array}{c}\text { Hailemariam Desalegn } \\
\quad(2012-2018)\end{array}$ & $\begin{array}{l}\text { Abiy Ahemd } \\
\text { (2018-) }\end{array}$ \\
\hline Accountability & $\downarrow$ & $\downarrow$ & $\downarrow$ & $\downarrow$ & $\downarrow$ \\
\hline Transparency & $\downarrow$ & $\downarrow$ & $\downarrow$ & $\downarrow$ & $\downarrow$ \\
\hline Respect & $\downarrow$ & $\downarrow$ & $\downarrow$ & $\downarrow$ & $\downarrow$ \\
\hline Cohesiveness & $\downarrow$ & $\downarrow$ & $\downarrow$ & $\downarrow$ & $\downarrow$ \\
\hline Integrity & $\downarrow$ & $\rightarrow$ & $\downarrow$ & $\downarrow$ & $\downarrow$ \\
\hline Democracy & $\rightarrow$ & $\downarrow$ & $\downarrow$ & $\downarrow$ & $\downarrow$ \\
\hline Novelty & $\downarrow$ & $\downarrow$ & $\downarrow$ & $\downarrow$ & $\downarrow$ \\
\hline Ego & $\uparrow$ & $\uparrow$ & $\uparrow$ & $\uparrow$ & $\uparrow$ \\
\hline Assassination & $\uparrow$ & $\uparrow$ & $\uparrow$ & $\uparrow$ & $\uparrow$ \\
\hline Intimidation & $\uparrow$ & $\uparrow$ & $\uparrow$ & $\uparrow$ & $\uparrow$ \\
\hline Injustice & $\uparrow$ & $\uparrow$ & $\uparrow$ & $\uparrow$ & $\uparrow$ \\
\hline Favoritism & $\uparrow$ & $\uparrow$ & $\uparrow$ & $\uparrow$ & $\uparrow$ \\
\hline
\end{tabular}

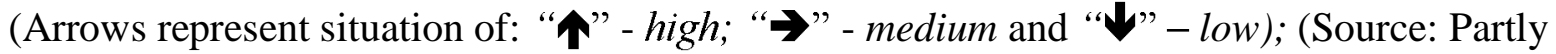
adopted from Gill (2010) \& Wigington (2019))

All these years, the Ethiopian leaders have continued manipulating the nation for their own personal and/or group benefits without any valid accountability. An assessment of Ethiopian leaders' attributes shows that most of them demonstrated bad leadership behavior (e.g., suppression, corruption, dishonesty, intimidation, etc.) than good leadership quality (As shown in Table 3 above). Kets de Vries characterizes autocratic leaders as:

Dictators prohibit all associations between citizenry that could lead to free debate, knowing that the loss of 'voice', the inability to speak one's mind and talk with others who cherish similar 'apostate' ideas, enhances feelings of isolation. To ensure that the populace cannot coordinate any form of political opposition, tyrants suppress or destroy all organizations and individuals that espouse views diverging from the main secular or theocratic ideology. To that end, they rely on an elaborate network of spies 
and informers, and they use police terror to prevent lateral communication (Kets de Vries, 2004, p.170).

The contemporary Ethiopian leaders understand intuitively the psychological vulnerability of humans and tried to keep their subjects isolated. They went to great lengths to break up traditional relationship patterns and dismissed opportunities often provided to their population or citizen. In this respect, an informant stated as:

Ethiopia never had a strong and visionary leader. The political elites who came to power at different times have adopted patrimonialism, clientelism, and patronage which have led to a partisan political system. There has not been democratic governance in the history of the country. Political disruptions, associated with social unrest and conflicts over the past decades have adversely impacted the political, social, and economic development of the country (KI: $\mathrm{PO} / \mathrm{SO})$.

\section{Lack of Diversity within Unity}

Modern Ethiopia was founded in the last decade of the $19^{\text {th }}$ century by merging the northern and southern blocks of todays' Ethiopia. Since then, unifying Ethiopia remains a big national challenge. Ethiopia possesses over 80 ethnic-national groups and is recognized as one of the diverse nations. Ethiopia's political system, however, has been highly centralized and dominated by a single identity until the late $20^{\text {th }}$ century (Gudina, 2007). The vast majority of the southern block of Ethiopia has been subjected to political suppression, economic marginalization, and cultural dehumanization for years. Historical inequality in the political system has created a sense of grievance, discontent, and disassociation among many ethnic groups in Ethiopia. The paradigms of oppression led to long years of civil wars, violation of human rights, poverty, and misery in monumental proportions that led to anti-unity. When EPRDF took power in 1991, there were many liberation fronts in the country that all fought for either self-determination or independence that showed how the unity of the country was under question. Failure to have 'Diversity within Unity' has made it complex for Ethiopia to make its people an endearing force for the country's development efforts. Given the historic and recent ongoing alienated political system, 'Diversity within Unity' remains a scary national challenge in today's Ethiopia. The dichotomy is still vibrant among the Ethiopian elites. 
The purpose here is, however, not to discuss lack of unity, but rather opted to demonstrate how lack of recognizing diversity within unity can influence development. Ethiopia as a nation has continuously lost golden opportunities (the 1960s, 1970s, 1990s, and 2000s) to become a prosperous country. The economic growth of Ethiopia was partly wrecked owing to the internal conflict that prevailed over many years. Even today, the political environment is not based on comprehensive reconciliation and different groups have different views; and which at the end of the day obstructs the development of Ethiopia. Nowadays, the Ethiopian population is highly divided and even they do not have common ground on the national emblem and flag - leave alone on the philosophy of development (Gudina, 2007; Lorch, 1995; Poluha \& Feleke, 2016).

Given the old-aged favoritism to the political system in the country, the people of Ethiopia have been troubled by the never-ending atrocities. Atrocities have pushed some groups/people to contend that this is not their government and country. It is the prowling of public resources by a few and the severe shady activities which have led some Ethiopians to think as if they have not been part of the equation of diversity within unity. Orchestrated by dissimilarity in political and economic injustice by folks who assert to represent one ethnic group - to be viewed with greater anger thereby harboring resentment and escalating the polarization and resulted in the fragmented nation-building. Many remained on what was noted as an 'exit option'. Innovative ways need to be devised to strengthen Diversity within Unity to make people a winning and unified force for the country.

\section{Controlled Freedom of Speech}

Historical sources indicate that most media outlets in Ethiopia are owned by the government until very recently although funded by taxpayers' money. The recently emerged independent national media are not only small but also self-censored and steer controversial political issues out of fear of harassment (Canela, 2014; Mukundu \& Rasmussen, 2018). In modern Ethiopia, freedom of expression was for the first time given juridical recognition in the 1955 Revised Constitution of Ethiopia; and further reiterated in the 1974 Draft Constitution and the 1987 Constitution of Ethiopia. However, none of these constitutional guarantees were effective and there was hardly any free press or freedom for political difference notwithstanding what these constitutions provided (Timothewosim, 2010; Mukundu \& Rasmussen, 2018). The 1995 FDRE 
Constitution also further granted freedom of expression more than ever before even if the practice on the ground has been debatable to date (e.g., Article 29, 30).

Article 19 of the Universal Declaration of Human Rights (UDHR) of United Nations states that "Everyone has the right to freedom of opinion and expression; this right includes freedom to hold opinions without interference and to seek, receive and impart information and ideas through any media and regardless of frontiers." In Ethiopia, over the years and even today, entitlement and freedom of seeking, receiving, and imparting information or ideas are very much controlled and scrutinized by the government. Some key informants (KI: PO/HI) expressed their frustration about the unprogressive development of freedom of expression; and the social, economic, and political impacts it brought to the nation. Century-old journeys to freedom of expression and speech have derailed Ethiopia. Many people have been detained or sanctioned or even killed by the government for voicing their opinions whether it is a protest, or individual opinion, or whatever means of information communication they used out of the government channel (Mukundu \& Rasmussen, 2018).

Freedoms of speech and expression are key elements of the development agenda for improved public policies, competent and effective governments, quality education, and to fight against corruption. As Canela (2014) states:

The right to freedom of speech in its triple challenge of ensuring the search for, reception, and transmission of information, ideas, and opinions by any means and platforms offered and still offers everyone a set of tools that are central to the processes of development: production and distribution of information; production and distribution of knowledge; participation in the drafting of public policies; monitoring of governments through accountability mechanisms; and the protection of other rights (p. 2).

In this way, we can affirm that freedom of expression in a democratic political system plays a critical role in driving development agenda through contributing towards the inclusion of essential themes of the public sphere of the contest and by acting as the watchdogs of government activities in the development process and therefore play a key role in the whole process of accountability. 


\section{Dependence on Aid and Assistance}

Ethiopia has been and remains prone to drought resulting from natural and human factors. Various sources (e.g., IIRR, 2007; Pankhurst, 1985) have indicated the incidence of drought over the last many years. Since the early 1970s, however, the magnitude, frequency, and impacts of drought have increased and extended to large parts of the country (IIRR, 2007). Drought often exposed millions of people to starvation/hunger and famine every year. Incapability to support afflicted populations frequently forced governments to submit an appeal for international development or humanitarian assistance. Ethiopia has been receiving aid in different forms (Mousseau, 2005; Geda \& Tafere, 2011; Hassan, 2013). Over the years, foreign assistance has shown some successes, but they are not as great as many thought due to the political, diplomatic, and economic interests of donors and receivers (Geda and Tafere, 2011; Hunt, 2004; Mousseau, 2005). Getting external support in the form of aid unfortunately created dependency syndrome by the government and affected community; and apparently, reduced their preparedness on selfreliance. International donors have also taken for granted the situation, and they did not push Ethiopia to be self-sufficient in the medium to long term goals. A combination of food aid recipients' and donors' attitudes have remained an impediment to the food self-reliance strategies of many developing countries including Ethiopia since the international food aid initiative started in the 1950s (Mousseau, 2005).

Foreign aid has without a doubt helped and saved millions of lives in crises. The impact of foreign assistance on the Ethiopian economy, however, was associated with increased inflation rates and dependency than improvement (Geda \& Tafere, 2011). According to Hassan (2013), the provision of development aid played and continued to play a big role in the development and institutionalization of state capture in Ethiopia. Hassan highlighted as:

The provision of welfare in the form of development assistance has reduced the government responsibilities to the people it ostensibly represented and reduced its legitimacy. Despite the huge annual influx of foreign aid (to the tune of $\$ 3.3$ billion by 2009 and rising), life in Ethiopia has gotten worse, not better - with the poor getting poorer, income inequality worsening, citizens leaving their country in a call trying to escape the onslaught of poverty and oppression that has been aided and abetted by foreign aid. Ethiopians are unable to realize their potentials because their 
rulers, who benefit in so many ways from the influx of foreign aid, would not let them get out of the aid trap and break the dehumanizing begging bowl (Hassan, 2013, p. 77).

Over years, international development assistance has shown mixed feelings concerning the impact of aid on development efforts in Ethiopia. Many informants (KI: EC/AN/DE/AG), nevertheless, asserted that foreign aid has negatively impacted the political, economic, and social wellbeing of the country of which, dependency syndrome and state capture have been evidenced by most informants.

\section{Fragile Public Policy Formulation and Implementation}

Governments often engaged in policy formulation and implementation to transform the social, economic, and political needs of their society. Policymaking is a decision about a proposal to be followed by the government in dealing with a societal problem (Cochran, 2015) whereas policy implementation is the process of changing a formulated policy into reality (Ajulor, 2018). A public policy determines the activities of governments and stakeholders about providing services designed to solve a given problem (Oni, 2016; Ajulor, 2018). Unrealistic policy formulation and implementation have been portrayed as one of the major development problems in developing countries (Dialoke et al., 2017). Often, a gap between stated policy goals and the realization of the planned goals is mostly hinged. Unsuccessful and fraudulent political leadership can also contribute to poor policy implementation. Corruption and incompetence of leadership influence the substance and quality of policy at the formulation stage. Politicians or political leaders make policies mostly to attract public compliments and thought concerning their correctness in addressing the given problems or the possibility of their effective practical implementation by the public bureaucracy.

In Ethiopia, successive governments have crafted different development policies that were not achievable throughout their tenure. Ethiopia has developed and adapted several policies that were mostly inappropriate or inconsistent to transform the nation to prosperity. There has been also a culture of discontinuity as the government changes. Over the last two decades, policy priorities led by the governments embarked on agriculture and rural-centered development - the Agricultural Development Led Industrialization (ADLI) encompassing poverty reduction and food security, commercialization, and export promotion. More recently, the development agenda 
focused on two strategies: the Growth and Transformation Plan (GTP), and the Climate Resilient Green Economy (CRGE). They prioritize the achievement of middle-income country status by 2025 by taking low carbon, resilient and green growth paths.

However, detectable challenges remain in the policy formulation and implementation processes such as lack of grassroots participatory policy-making, inadequate analytical skills, and knowledge, limited dialogue among the various stakeholders, and inadequate networking among the different stakeholders (EEA, 2011). The recent and past policy-making and implementation have failed short of the expectation; and renowned as a policy-making exercise with a limited transformation story. Policy-making seriously suffers from a lack of public engagement and participation. More often, these policies are incompatible with the objective reality of the country, and as a result, failed to transform the country to prosperity. As stated by some of the informants:

Ethiopia has been formulating some of its development policies and applying them to the country without carrying out proper piloting and experimentation. Most implemented development policies suffered from periodic failures. One can mention the present Educational Policy of EPRDF as a case in point where the graduates of the different programs have been left with low skill or unskillful owing to the untested policy implementation from elsewhere (KI: $\mathrm{PO} / \mathrm{HI})$.

Governments missed the gap between ideas of the best practice and the actual political, economic, legal, and administrative processes. The policymaking process in Ethiopia is a government realm, and stakeholders' participation is usually lacking. Policy development is more often oriented toward political perspective or/and donors driven, but when it comes to implementation, it is left disconnected mostly because of incompetency. Making the process participatory by engaging stakeholders may lead to the adoption of the new policy and then advance to the implementation stage. Any envisaged development or/and transformation should be supported by policies that must be properly formulated, implemented, and well monitored to avoid failures (Samson \& Stanley, 2014). The failure or success of any given policy is much influenced by the pattern and nature of policy implementation.

Thus, there must be an effective communication system between the policy-makers, the target beneficiaries, and the policy implementers. The culture of changing or discontinuing a policy 
once there is a change in government should be discouraged simply because the society will continue despite the change of government. There should be continuity regarding policy issues unless it is proved not to be in the service of the people. Politically acceptable policy formulation means that the proposed course of action is likely to be authorized by the legitimate decisionmakers, usually through support by the majority in a bargaining process (Ajulor, 2018).

\section{Inadequate Innovation, Incentive, and Entrepreneurship}

Society's transformation is immensely influenced by the level of its innovativeness. Innovation is the driver of development and without innovative entrepreneurs, the global community would not have been able to enjoy the tools and services that provide people with a success today that far exceed its ancient predecessors. More entrepreneurial activity is shifted toward productive entrepreneurship that strengthens economic development (Acemoglu \& Johnson, 2005). This entrepreneurial activity tends to explode during the innovation-driven stage of a society that culminates in a high level of innovation, with entrepreneurship leveling out as institutions are fully developed (Fukuyama, 1989). All societies may have a constant supply of entrepreneurial activity, but that activity was distributed unevenly between productive, unproductive, and destructive entrepreneurship because of the existence of incentive structure (Acs, 2010). To change the incentive structure, there is a need to strengthen policy and institutions, which further requires a need to fix the government or the political system.

Ethiopia lacks legal and institutional frameworks and incentive mechanisms that encourage the innovation and entrepreneurship behaviors of individuals/groups. Lack of societal innovation and entrepreneurship behaviors can seriously weaken societal transformation. Attributable to different reasons, the knowledge of Ethiopians has been and still low in understanding the need for novelty and entrepreneurship for national development. Innovation and entrepreneurship dealing are at an infant stage in Ethiopia until now. Ethiopia was repeatedly governed by dictators who often tried to build their legacy. In such a governance environment, if a person is engaged in innovation and gets fame he/she may be assumed as a betrayal to the leader or the system and liable to some kind of punishment. In this regard, one of the key informants states as:

The customary thoughts and institutions are still constraining the development of the country when some innovative ideas are either adopted or emanated in the different productive systems (KI: $\mathrm{SO})$. 
Traditional tool makers and innovators - blacksmiths, potteries, carpenters, weavers, leather workers, traditional healers, etc., have been reduced to sub-human status and corrupted that led to their near-extinction with all their nicknames and stigma.

\section{Underprivileged Working Culture}

Until recently, there have been many non-working days per week in Ethiopia owing to religious or social norms/celebrations. Majorities of Ethiopians are religious, and "humble" religious teachings have already been internalized in their minds. Religious people always think that this world is not theirs, and some do not crave a better life. So, social norms and religious dogma, mixed with culture, are hard to change, and they sometimes drive existing institutional differences. In this regard, one of the respondents stated as:

Ethiopians have been very much obsessed by cultural/religious and psychological demons such as strong cultural patterns that obstruct positive economic changes and undermining the trends of development. For example, different nicknames were given to those who work on metallurgy, woodwork, leather, etc. while these are important shifts in the productive systems of the country (KI: SO).

In Ethiopia, many people still remain poor because they lack a good work ethic or hard-working manners and unmoving/unchanging belief in witchcraft and bequest. There is a bad working culture and most Ethiopians are not workaholics. However, hardworking is the magic and the silver bullet of development which does not seem to exist as needed. There is also a culture of dependence on the family that is often considered as a norm for families to take care of their children even if they are 22 years old and university graduates. In this regard, one of the key informants stated as:

Strong work culture, common vision, endurance, creativity, innovativeness, etc. are largely lacking among Ethiopians. Creativity, and openness to experiment or experience, and the need for higher achievement are at a low level in all cultures. The country has not still gone through social and cultural changes/transformations. This has also been one of the impediments of the development endeavor of the country (KI: GS). 
On top of this, the stagnant politics and unrewarding governance structures for years have been and will continue to impede development. The socio-cultural-political landscapes within which people are placed and the source of resentment and endless conflict have dwarfed the common goods of the country.

\section{Conclusions and Recommendations}

The last three successive Ethiopian regimes messed up the development opportunities of the country. They were not able to bring about change owing to political instability, war, and conflicts, corruption, despotic leadership, and ill-sighted development policy and strategy. Political and economic institutions were extractive in the long history of the country. Unlike Ethiopia, for instance, many South Asian nations have revolutionized their political and economic institutions toward an inclusive approach and laid the foundations for subsequent growth and development. If Ethiopia has to come out of the quagmire of poverty and underdevelopment, it needs to scrutinize the political, economic, and social development pathways it followed; and devise mechanisms for future development opportunities. This paper, therefore, recommended the following points for better future development opportunities:

- Ethiopia never had popularly elected leaders and leadership throughout its history. Genuinely elected leaders are highly required to establish governance that enables legitimate and holistic transformation. In the past, Ethiopian leaders fought to establish their own legacy instead of transforming the nation. The country must fight once for all and get rid of self-elected leaders and put in place a system of accountability for the better future and wellbeing of its population.

- Political instability has been and remains to be the common phenomenon of contemporary Ethiopia. Achieving prosperity depends on solving basic political instability that directly entails solutions to economic problems. If Ethiopia has to come out of poverty and underdevelopment, it needs to improve its political stability and governance system.

- Ethiopia has been a center of experimentation for many inadequate policies/strategies; and misguided policy implementation in the absence of accountability. The culture of changing policies following a change in government should wane. 
- Corruption has been the de facto government system of Ethiopia until now. Thus, the country needs to put in place strong mechanisms that ensure transparency and accountability in the government and political system.

- Many Ethiopians have remained poor because of a lack of a good work ethic or hardworking manners and unmoving belief in witchcraft and bequest. Hard-working is the magic and the silver bullet for development.

- In Ethiopia, over the years and even today, rights to entitlements and freedoms of seeking, receiving, and imparting information or ideas are very much controlled and scrutinized by the government. Freedom of expression plays a critical role in driving development by acting as the watchdogs of government activities. This is one of the areas where the Ethiopian government needs to explore and improve for a better future.

- Failure to have 'diversity in unity' has made it complex for Ethiopia to make its people an endearing force for development efforts. Given the historic and the recent ongoing alienated political system, 'diversity in unity' remains a scare national challenge in today's Ethiopia. Innovative ways need to be devised to strengthen unity in diversity to make its people a winning force for the country.

- The economic success of the Asian Tigers has served as a role model for many developing countries, where Ethiopia can learn from it and scan its future development horizon for improvement.

\section{References}

Abuiyada, R. (2018). Traditional development theories have failed to address the needs of the majority of people at grassroots levels with reference to GAD. International Journal of Business and Social Science 9(9):115-119.

Acemoglu, D. \& Robinson, J. (2012). Why nations fail. New York: Crown Business.

Acemoglu, D., \& Johnson, S. (2005). Unbundling institutions. Journal of Political Economy 113(5): 949-995.

Acs, Z.J. (2010). Entrepreneurship and economic development: The valley of backwardness. Annals of Innovation and Entrepreneurship 1:1. DOI: 10.3402/aie.v1i1.5602.

Adams, W.M. (2009). Green development: Environment and sustainability in a developing world ( $3^{\text {rd }}$ ed.). New York: Routledge.

Adejumobi, S.A. (2007). The history of Ethiopia. Westport: Greenwood Press. 
Agbiboa, D.E. (2012). Between corruption and development: The political economy of state robbery in Nigeria. Journal of Business Ethics 108:325-345.

Ajulor, O.V. (2018). The challenges of policy implementation in Africa and sustainable development goals. People: International Journal of Social Sciences 3(3):1497-1518.

Asrat, A. (2016). The Ethiopian highland massifs: Spectacular volcanic landscapes with high biodiversity. In Anhaeusser C. R., Viljoen M. J., Viljoen R.(eds.). Africa's Top Geological Sites. Cape Town: Struik Nature, pp. 189-196.

Bayly,C.A. (2008). Indigenous and colonial origins of comparative economic development: The case of colonial India and Africa. Policy Research Working Paper 4474, The World Bank.

Bekele, Y.W., Kjosavik, D.J.\& Shanmugaratnam, N. (2016). State-society relations in Ethiopia: A political-economy perspective of the post-1991 order. Social Sciences 5(3):48:1-19. DOI: $10.3390 /$ socsci5030048.

Broadman, H.G. \& Recanatini, F. (2001). Seeds of corruption - Do market institutions matter? Economic Policy in Transitional Economies 11(4): 359-392.

DOI: $10.1023 / \mathrm{A}: 1015264312632$

Canela, G. (2014). Freedom of speech as a key element of the development agenda.https://www.observacom.org/freedom-of-speech-as-a-key-element-of-thedevelopment-agenda/(Accessed: 27 April 2020).

Clapham, C. (2015). The era of Haile Selassie. In Prunier G, Éloi F. (eds). Understanding contemporary Ethiopia: Monarchy, revolution and the legacy of Meles Zenawi. London: Hurst \& Company.

Cochran, C.L. (2015). Public policy: Perspectives and choices $\left(3^{\text {rd }}\right.$ ed.). USA: Lynne Rienner Publishers.

Cohen, J.M. (1974). Peasants and feudalism in Africa: The case of Ethiopia. Canadian Journal of African Studies 8(1):155-157.

Creswell, J.W. (2009). Research design: Qualitative, quantitative, and mixed methods approaches $\left(3^{\text {rd }}\right.$ ed.). Thousand Oaks, CA: Sage Publications.

Darbyshire, I, Lamb, H. \& Umer, M. (2003). Forest clearance and regrowth in northern Ethiopia during the last 3000 years. The Holocene 13 (4): 537-546.

Dialoke, I, Finian, U. \& Veronica, M.I. (2017). Policy formulation and implementation in Nigeria: The bane of underdevelopment. International Journal of Capacity Building in Education and Management (IJCBEM) 3 (2): 22-27.

Eshetu, Z. \& Högberg, P. (2000). Reconstruction of forest site history in Ethiopian highlands based on 13C natural abundance of soils. AMBIO: A Journal of the Human Environment 29 (2): 83-89.

Flynn, J. (2005). Ethiopia: What can be done? Student Economic Review 19: 253-263.

Fukuyama, F. (1989). The end of history? The National Interest (No.16): 3-18.

Geda, A. \& Tafere, K. (2011). Official development assistance (Aid) and its effectiveness in Ethiopia. Institute of African Economic Studies. IAES Working Paper Serious No-A072011:1-33. 
Gill, P. (2010). Famine and foreigners: Ethiopia since live aid. New York: Oxford University Press.

Gudina, M. (2007). Ethnicity, democratization and decentralization in Ethiopia: The case of Oromia. Eastern Africa Social Science Research Review 23 (1):81-106.

Hassan, S. (2013). Aid, predation and state capture: the role of development aid in fuelling corruption and undermining governance: the case of Ethiopia. Ethiopian e-Journal for Research and Innovation Foresight (Ee-JRIF) 5(1):51-93.

Hassan, S. (2016). Ethiopia: The people want their country back. Pambazuka.https://www.pambazuka.org/governance/ethiopia-people-want-their-countryback (Accessed: 26 April 2020).

Hicks, N. \& Streeten, P. (1979). Indicators of development: The search for a basic needs yardstick. World Development 7(6):567-580.

HRLHA. (2020). Ethiopia: Politically motivated mass arrests make the coronavirus (COVID-19) risk worse. Human Rights League of the Horn of Africa (HRLHA) Press Release. https://www.humanrightsleague.org/?page_id=14550 (Accessed: 16 April 2020).

HRW. (2010). Development without freedom: how aid underwrites repression in Ethiopia. (Accessed:http://www.hrw.org/sites/default/files/reports/ethiopia1010webwcover.pdf (Accessed: 16 Apr 2020).

HRW. (2020). Human Rights Watch (HRW) World report|2020 Events of 2019.https://www.hrw.org/sites/default/files/world_report_download/hrw_world_report_ 2020_0.pdf (Accessed: 16 April 2020).

HRW/Africa. (1997). Curtailment of rights. Human Rights Watch 9 (8A).

Hunt, J. (2004). Aid and development. In Kingsbury D, Remenyi J, Mckay J, J. Hunt J (eds). Key issues in development. New York: Palgrave Macmillan.

ICG. (2020). Managing the politics of Ethiopia's Covid-19 crisis. https://www.crisisgroup.org/africa/horn-africa/ethiopia/managing-politics-ethiopiascovid-19-crisis (Accessed: 16 April 2020).

IIRR. (2007). Leaving disasters behind: A guide to disaster risk reduction in Ethiopia. International Institute of Rural Reconstruction (IIRR), Nairobi \& Save the Children USA, Addis Ababa.

Keller, E. (1991). Revolutionary Ethiopia: From empire to people's republic. Bloomington: Indiana University Press.

Kuznets, S. (1966). Modern economic growth: Rate, structure and spread. Connecticut: Yale University Press.

Lawan, M.A. (2008). The paradox of underdevelopment amidst oil in Nigeria: A socio-legal explanation. PhD Thesis, University of Warwick.

Lewis, C.H. (1998). The paradox of global development and the necessary collapse of modern industrial civilization. In Dobkowski M. N. \& Wallimann I. (eds). The coming age of scarcity: Preventing mass death and genocide in the twenty-first century. New York: Syracuse University Press.

Lie, J.H.S. \& Mesfin, B. (2018). Ethiopia: A political economy analysis. Norway: Norwegian Institute of International Affairs.

Lorch,D. (1995). Ethiopia deals with legacy of kings and colonels. The New York Times. https://www.nytimes.com/1995/12/31/world/ethiopia-deals-with-legacy-of-kings-andcolonels.html (Accessed 30 March 2020).

Marcus, H.G. (1994). A history of Ethiopia. Berkeley: University of California Press. 
Marshall, P.A. (2003). Human subjects protections, institutional review boards, and cultural anthropological research. Anthropol $Q$ 76(2):269-285. DOI: 10.1353/anq.2003.0028

Mousseau, F. (2005). Food aid or food sovereignty? Ending world hunger in our time. Oakland: The Oakland Institute.

Mukundu, R. \& Rasmussen, F. (2018). Media and freedom of expression assessment Ethiopia in transition: Hope amid challenges. Copenhagen: International Media Support (IMS).

Nicholas, C. (1989). Theories of development and the underdevelopment of the Orang Asli. Akademika : Jurnal Sains Kemasyarakatan dan Kemanusiaan 35: 55-68.

Oni, E.O. (2016). Public policy analysis. In Fundamental of Political Governance. https://www.researchgate.net/publication/334749461 (Accessed: 6 May 2020).

Pankhurst, R. (1985). The history of famine and epidemics in Ethiopia: Prior to the twentieth century. Addis Ababa: Relief and Rehabilitation Commission.

Peebles, G. (2013). Displacement, intimidation and abuse: land loyalties in Ethiopia. https://www.opendemocracy.net/en/ (Accessed: 10 April 2020).

Phillipson, D.W. (1985). African archaeology. Cambridge: Cambridge University Press.

Pieterse, J.N. 2010. Development theory: Deconstructions/reconstructions. London: Sage Publications Ltd.

Plaut, M. (2012). The legacy of Meles Zenawi. Review of African Political Economy 39(134): 645-654. DOI: 10.1080/03056244.2012.738796

Poluha, E. \& Feleke, E. (2016). Thinking outside the Box: Essays on the history and (under) development of Ethiopia. Bloomington: Xlibris Publisher.

PRB. (2020). 2020 world population data sheet. Washington: Population Reference Bureau (PRB).

Pritchett, L., Woolcock, M. \& Andrews, M. (2013). Looking like a state: Techniques of persistent failure in state capability for implementation. The Journal of Development Studies 49(1):1-18.

Prunier, G. (2015). The Ethiopian revolution and the Derg regime. In Prunier G, Éloi F. (eds). Understanding contemporary Ethiopia: Monarchy, revolution and the legacy of Meles Zenawi. London: Hurst \& Company.

Rapley, J. (2007). Understanding development: theory and practice in the third world. USA: Lynne Rienner Publishers.

Remenyi, J. (2004). What is development? In Kingsbury D, Remenyi J, Mckay J, Hunt J (eds). Key issues in development. New York: Palgrave Macmillan.

Samson, E. \& Stanley, A. (2014). Public policy failures in Nigeria: Pathway to underdevelopment. JPPAR 4 (9): 38 - 43.

Shepsle, K. \& Bonchek, M. (2010). Analyzing politics. New York: W. W. Norton \& Company.

Smith, M.H., Hargroves, K.J. \& Desha, C.K. (2010). Cents and sustainability: Securing our common future by decoupling economic growth from environmental pressures. United Kingdom: Earthscan Publications.

Teferra, D. (1984). The lack of development in Ethiopia. Northeast African Studies 6(1/2):13-22.

The Ethiopian Economics Association (EEA). (2011). The development of key national policies with respect to rainwater management in Ethiopia: A review. Challenge Program on Water and Food (CPWF) Nile coordination and multi-stakeholders platform (Project 5). Addis Ababa: International Livestock Research Institute (ILRI).

Timothewos, G. (2010). Freedom of expression in Ethiopia: The jurisprudential dearth. Mizan Law Review 4(2): 201-231. 
Feyera, S., The Paradox of Ethiopia's Underdevelopment: Endogenous Factors in Retrospect

Todaro, P. \& Smith, C. (2003). Economic development $\left(8^{\text {th }}\right.$ ed.). New York: Pearson Education. Transparency International. (2018). Corruption perception index (CPI) 2018. Germany: Transparency International.

UNDP. (2018). Human development indices and indicators: 2018 statistical update. New York: UNDP.

UNDP. (2019). Global multidimensional poverty index 2019: Illuminating inequalities. New York: UNDP.

UNEP. (2010). Africa water atlas: Division of early warning and assessment (DEWA). Nairobi: United Nations Environment Program (UNEP).

VonGrebmer, K., Bernstein, J., Mukerji, R., Patterson, F., Wiemers, M., NíChéilleachair, R., Foley, C., Gitter,S., Ekstrom, K. \& Fritschel, H. (2019). 2019 global hunger index: The challenge of hunger and climate change. Bonn: Welthungerhilfe.

World Bank. (2016). World development indicators 2016. Washington, DC: World Bank. 